\title{
PEMBERIAN RANSUM KOMBINASI HERBAL DENGAN MINERAL ZINK TERHADAP PERFORMANS AYAM BROILER YANG DIINFEKSI Escherichia coli
}

\author{
M.N.Regar ${ }^{1}$, R. Mutia $^{2}$, S.D.Widhyari ${ }^{3}$, dan Y.H.S.Kowel ${ }^{1}$ \\ ${ }^{1}$ Fakultas Peternakan Universitas Sam Ratulangi Manado \\ ${ }^{2}$ Fakultas Peternakan Institut Pertanian Bogor \\ ${ }^{3}$ Fakultas Kedokteran Hewan Institut Pertanian Bogor
}

\begin{abstract}
ABSTRAK
Penelitian ini dilakukan untuk menguji pengaruh pemberian kombinasi herbal dengan mineral zink dalam ransum broiler yang diinfeksi Escherichia coli (E. coli). Dua ratus ekor d.o.c (day old chick) dibagi secara acak ke dalam lima perlakuan, masing-masing perlakuan diulang empat kali sehingga terdapat 20 unit percobaan, setiap unit percobaan terdiri dari 10 ekor d.o.c. Anak ayam percobaan dipelihara selama 35 hari. Ransum perlakuan terdiri dari R1 = Pakan basal/ ayamsehat (kontrolnegatif); R2 = Pakan basal/ ayamdiinfeksiE.coli (kontrolpositif); R3= Pakan basal + serbukkunyit $1.5 \%+\mathrm{ZnO} 180 \mathrm{ppm} /$ ayamdiinfeksiE.coli; R4 = Pakan basal + serbukbawangputih $2.5 \%+\mathrm{ZnO} 180$ $\mathrm{ppm} /$ ayamdiinfeksiE.coli; R5 = Pakan basal + antibiotik/ ayamdiinfeksiE.coli.Penelitian

menggunakan rancangan acak lengkap. Peubah yang diamati konsumsi ransum, pertambahan bobot badan, dan konversi ransum. Hasil dari penelitian ini menunjukkan bahwa pemberian kombinasi kunyit $1.5 \%$ dengan $\mathrm{ZnO} 180$ ppm dan kombinasi bawang putih $2.5 \%$ dengan zink $180 \mathrm{ppm}$ dalam ransum mampu memperlihatkan performa yang lebih baik.
\end{abstract}

*JurusanProduksi Ternak

\section{Kata Kunci:}

\begin{abstract}
This experiment was conducted to study the combination of herbal with zink in poultry diet on the performance of Escherichia coli challenged broiler. Two hundred d.o.c unsexed were devided into five treatments and four replications, with ten chicks in each replicates. The treatments were R1 (basal diet as a negative control/ healhty chickens), R2 (basal diet as a positive control/ Escherichia coli challenged), R3 (basal diet $+1.5 \%$ turmeric powder $+\mathrm{ZnO}$ $180 \mathrm{ppm} /$ Escherichia coli challenged), $\mathrm{R} 4$ (basal diet $+2.5 \%$ garlic powder + $\mathrm{ZnO} 180 \mathrm{ppm} /$ Escherichia coli challenged), and R5 (basal diet + antibiotic/ Escherichia coli challenged). Data were collected during 35 days, diet and water were offered ad libitum. The results of this research indicated that chickens fed basal diet $+1.5 \%$ turmeric powder + ZnO $180 \mathrm{ppm} /$ challenged Escherichia coli and chickens fed basal diet $+2.5 \%$ garlic powder $+\mathrm{ZnO} 180$ $\mathrm{ppm} /$ challenged Escherichia coli showed performances better than control .
\end{abstract}


Keywords: Sweet potato leaves, Body weight, Consumtion ration, Convertion ration, Broiler

\section{PENDAHULUAN}

Industri perunggasan merupakan salah satu industri yang cukup penting dalam penyediaan protein hewani dan merupakan sumber pendapatan bagi masyarakat. Pencegahan dan pengendalian penyakit adalah salah satu kendala dalam industri perunggasan. Daya tahan tubuh ternak sangat penting peranannya dalam menangkal berbagai macam penyakit. Daya tahan erat kaitannya dengan sistem kekebalan tubuh yang ditunjang oleh fungsi sel imun serta produksi antibodi. Sistem pertahanan yang semakin baik, sistem imun tubuh semakin tangguh melawan berbagai agen infeksi. Pakan merupakan salah satu faktor yang berperan dalam peningkatan daya tahan tubuh ternak. Kecukupan zink (Zn) dalam pakan diduga berperan dalam peningkatan daya tahan tubuh. Menurut Zinc information (2008) zink sangat esensial dalam mengatur sel normal sebagai media fungsi sistem imun tubuh.

Upaya pencegahan penyakit
yang telah dilakukan selain
penggunaan zink dalam ransum yaitu
dengan pemberian
antibiotik.Penggunaanantibiotikdalam
pakanternakbertujuansebagaipemacup
ertumbuhan,
untukmemperbaikiefisiensipenggunaa
npakandanpencegahanterhadapkemun
gkinaninfeksi patogen (Solomon,

1978).

Antibiotikdipercayadapatmenekanpert umbuhanbakteri-bakteri patogen yangberakibatmelambungnyapopulasi bakterimenguntungkandalamsaluranpe ncernaan. Tingginya mikroflora menguntungkantersebutdapatmerangsa ngterbentuknyasenyawa-senyawa antimikrobial, asamlemakbebasdanzatzatasamsehinggaterciptanyalingkunga nkurangnyamanbagipertumbuhanbakte ri patogen (Samadi, 2004).

Penggunaanantibiotikinimulaim emberikanmasalahyangseriusyaitudite mukannya residu antibiotikdalamkarkasternakyangakhir nyameningkatkanprevalensi kasus penyakitinfeksiyangresistanterhadapan tibiotikpadamanusia (Revington, 2002). Residu antibiotik akan terbawadalamproduk-

produkternaksepertidaging, telur, dansusu, dan akan berbahayabagikonsumenyangmengkon sumsinya. RusianadalamSamadi (2004) melaporkandari 80 ekor broiler di Jabodetabek $85 \%$ daging broiler dan $37 \%$ hatiayamtercemar residu antibiotiktylosin, penisilin, oxytetracyclinedankanamycin.

Berbagaialternatifmulaidikemba ngkanuntukmencarialternatifbahanpak antambahanyanglebihaman, antaralainmelaluipenggunaanenzim, probiotik, prebiotik, asamasamorganik, rempahrempahdanekstraktanamanobat (Wenk, 2000).

Penggunaanherbaldalampakanm enjadisalahsatualternatifuntukmengata simasalahtersebut, yaitudenganmenggunakanherbalkunyit danbawangputih.

Penggunaanherbalkunyitdanbawangpu tihsecaratunggaltelahbanyakdilakukan, 
namunpenggunaandenganmengkombi nasikankeduaherbaltersebutditambah mineral zink belumadapenelitianyangmelaporkan. Kunyitdimanfaatkanuntukmena mbahcerahatauwarnakuningkemeraha npadakuningtelur, jikadicampurkanpadaransumayam, dapatmenghilangkanbaukotoranayamd anmenambahberatbadanayam, juga minyakatsirikunyitbersifatantimikroba (Winarto, 2003). Pemberiankunyitpadataraf $\quad 0.6 \%$ dalamransum broiler memberikanhasilterbaikpadaperforma broiler

yaitumampumeningkatkankonsumsira nsumdanpertambahanbobotbadan broiler (Agustina, 1996). Hardian (2004),

penambahantepungkunyitdalamransu mberpengaruhsangatnyataterhadappert ambahanbobotbadanmencitumur 35 haridenganpenambahantepungkunyit 4 $\%$. ih,

Komponenaktifdalambawangput

allicinmerupakanzataktifyangmempun yaidayabunuhpadabakteridan anti radang;

alliinmerupakansuatuasamaminoantibi otikdanmenurunkan kolesterol darahdandaging broiler (Jaya, 1997). Wiryawanet al. (2005) menggunakan metode

pembubukanbawangputihdengan dosis 2.5

dalammengatasiseranganSalmonella typhimuriumpadaayampedaging.

Bubukbawangputihsebanyak $2.5 \%$ dalamransumdapatmenurunkan koloni bakteriSalmonella typhimurium.Agustina (2003), penggunaanekstrakbawangputihdenga nkonsentrasi dapatmenanggulangikecacinganpadaa yampetelur. Suharti (2004) melaporkanpemberianserbukbawangp utih $2.5 \%$ dalamransumdapatmeningkatkankonv ersiransum, meningkatkanpersentasekarkas, sertamenurunkan koloni bakteriSalmonella typhimurium. Mineral zink dalambentuk zink inorganikmempunyaifungsimeningkat kan performans danresponimunterhadap broiler (Ali et al. 2003).

Berdasarkanlatarbelakang di atas maka

dilakukanpenelitiantentangpenggunaa nkombinasikunyit, bawangputih dengan zink dalampakan broiler terhadapperforma. Selanjutnya, dalampenelitianinitantanganEscherichi acoli (E. coli) diperlukanuntukmengetahuiseberapaja uhkemampuanpemberiankombinasiher bal-Znmampumenekanmunculnya kasus kolibasilosis, sertakemampuannyadalammenanggula ngikejadiankolibasilosisyangmerupaka nsalahsatupenyakitbersifat fatal danmenyebabkankematiancukuptinggi

\section{MATERI DAN METODE PENELITIAN}

Ayam percobaan yang digunakan berumur sehari sebanyak 200 ekor strain Hybro produksi PT Manggis Farm. Ransum kontrol yang digunakan terdiri dari jagung, dedak, minyak kelapa, tepung ikan, bungkil kedelai, $\mathrm{CaCO}_{3}$, DCP, premiks, lysin dan methionin. Ransum di buat dalam bentuk crumble. Kandungan protein ransum $24.62 \%$ dan GE $3842 \mathrm{kkal} / \mathrm{kg}$ untuk periode starter dan kandungan 
$\begin{array}{ccr}\text { Hasil } & \text { analisis } & \text { statistik } \\ \text { menunjukkan } & \text { bahwa } & \text { pemberian }\end{array}$ kombinasi kunyit, bawang putih dengan zink tidak mempengaruhi konsumsi ransum selama penelitian (sebelum dan sesudah infeksi E. coli). Infeksi $E$. coli yang diberikan belum mempengaruhi konsumsi ransum dan semua jenis ransum memiliki palatabilitas yang sama. North (1984) mengatakan bahwa konsumsi ransum dipengaruhi oleh kualitas bahan dan palatabilitas.

Hasil analisis statistik menunjukkan bahwa pertambahan bobot badan sebelum infeksi $E$. coli nyata $(\mathrm{P}<0.05)$ dipengaruhi oleh pemberian kombinasi kunyit, bawang putih dengan zink dalam ransum. Sesudah infeksi E. coli, pertambahan bobot badan nyata lebih tinggi perlakuan R1 daripada perlakuan R2, R3, R4, dan R5. Hal ini karena perlakuan R1 tidak diinfeksi E. coli, sementara diantara perlakuan yang diinfeksi E. coli perlakuan R3 menunjukkan pertambahan bobot badan tertinggi, disebabkan oleh adanya kurkumin dalam kunyit dan mineral $\mathrm{Zn}$ yang berfungsi dalam peningkatan nafsu makan yang diikuti oleh terjadinya peningkatan bobot badan. Penggunaan serbuk kunyit memberikan efek menguntungkan pada lambung dengan meningkatkan sekresi musin yang berfungsi sebagai pelindung mukosa lambung dari bahan iritan, sehingga proses pencernaan tidak terganggu (Lee, 2004).

Hasil analisis statistik menunjukkan konversi ransum perlakuan R2, R3, R4 dan R5 nyata $(\mathrm{P}<0.05)$ lebih rendah daripada $\mathrm{R} 1$ sebelum infeksi E. coli. Pemberian kombinasi bawang putih dengan zink memberikan pengaruh yang positif ditunjukkan dengan rendahnya nilai konversi ransum dibandingkan perlakuan lainnya. Konversi ransum sesudah diinfeksi $E$. coli tidak menunjukkan perbedaan diantara perlakuan dan nilai konversi terendah pada perlakuan R4. Hal ini disebabkan adanya allicin dalam bawang putih yang berfungsi sebagai antimikroba, yang mampu membunuh mikroorganisme merugikan sehingga populasi bakteri menguntungkan menjadi seimbang dalam tubuh, dengan demikian proses penyerapan zat makanan di dalam usus halus tidak terhambat dan akan lebih sempurn (Purwanti, 2008).

\section{KESIMPULAN}

Pemberian kombinasi kunyit $1.5 \%$ dengan $\mathrm{ZnO} 180 \mathrm{ppm}$ dan kombinasi bawang putih $2.5 \%$ dengan $\mathrm{ZnO} 180$ ppm dalam ransum memperlihatkan performans yang lebih baik.

\section{DAFTAR PUSTAKA}

Agustina A. 1996. Penggunaan tepung kunyit (Curcuma domestica) dalam ransum terhadap penampilan dan daya tahan tubuh ayam pedaging [Skripsi]. Bogor: Fakultas Peternakan, Institut Pertanian Bogor.

Agustina. 2003. Atasi infeksi cacing dengan bawang putih. Infovet No.111:44-45.

Ali S.A., M.A.M. Sayed, S.A. Elwafa, A.G.Abdallah. 2003. Performance and immune response of broiler chick as affected by methionine and zinc 
or commercial zink-methionine supplementations [abstrak]. Di dalam: J Egypt Poult Sci; Egypt: Animal Production Research Insitute, ARC, Dokki. hlm 523540. Abstr vol.23 no.3.

Hardian S. 2004. Performa hasil silangan mencit agouti dan mencit putih pada penambahan tepung kunyit (Curcuma domestica, Val.) dalam ransum [Skripsi]. Bogor: Fakultas Peternakan, Institut Pertanian Bogor.

Jaya I.N.S. 1997. Pengaruh penambahan bawang putih (Allium sativum L.) dalam pakan pada kadar kolesterol ayam broiler [Tesis]. Bogor: Program Pascasarjana, Institut Pertanian Bogor.

North M.O. 1984. Commercial Production Manual. Ed ke-4. Connecticut: Avi Publishing Company Inc.

Purwanti S. 2008. Kajian efektifitas pemberian kunyit, bawang putih dan mineral zink terhadap performa, kadar lemak, kolesterol dan status kesehatan broiler [Tesis]. Bogor: Program Pascasarjana, Institut Pertanian Bogor.

Revington B. 2002. Feeding Poultry in The Post-Antibiotics Era. Onario: New-Life Mills Limited. 1400 Bishop Street. Suite 201. Cambridge.

Samadi. 2004. Feed quality for food savetykapankahIndonesia?.Inova si Vol.2/XVI.
Solomon I.A. 1978. Antibiotics in Animal feeds-human and animal safety issues. $J$ Anim Sci 46:1360-1368.

Steel R.G.D., dan J.H. Torrie. 1995. Prinsip dan Prosedur Statistika. Suatu Pendekatan Biometrik. Edisi ke-2. Sumantri B, penerjemah; Jakarta : Gramedia Pustaka Utama.

Suharti S. 2004. Kajian antibakteri temulawak, jahe dan bawang putih terhadap bakteri Salmonella thphimurium serta pengaruh bawang putih terhadap performans dan respon imun ayam pedaging [Tesis]. Bogor: Program Pascasarjana, Institut Pertanian Bogor.

Wenk C. 2000. Herbs, species and botanicals: "old fashioned" or the new feed additives for tomorrows feed formulation?. concepts for their successful use. Di dalam: Biotechnology in Feed Industry. Proceedings of Alltech's $16^{\text {th }}$. Annual Symposium, hlm 79-96.

Wiryawan KG, S. Suharti, dan M. Bintang. $2005 . \quad$ Kajian antibakteri temulawak, jahe, dan bawang putih terhadap Salmonella typhimurium serta pengaruh bawang putih terhadap performans dan respon imun ayam pedaging. Media Peternakan 28(2): 52-62.

Zink information. 2008. Zinc. http://www.mindat.orgmin29191.html [Mar 2008] 